Шевцов С. О.

\title{
АНАЛІЗ ВПЛИВУ ВИБОРУ ТЕМПЕРАТУРНОГО РЕЖИМУ ПРОЦЕСУ РОТАЦИЙНОГО ОБКОЧУВАННЯ ІНСТРУМЕНТОМ ТЕРТЯ НА ГЕРМЕТИЧНІСТЬ ДНИЩ БАЛОНІВ
}

В сучасних економічних умовах українського машинобудування важливим завданням $\epsilon$ підвищення конкурентоспроможності продукції за рахунок зниження собівартості та підвищення якості виробленої металопродукції. Значне місце серед промислових виробів займає продукція, що має днище (газові балони, корпуси вогнегасників та ін.). Балони виготовлені 3 декількох частин (пустотілий корпус, днище та горловина), які зварюються, не гарантують високу надійність з'єднання металу днища й корпусу балону, а також вимагають значної кількості різноманітних виробничих операцій та обладнання. До того ж за цих умов під дією високого тиску можливий обрив днища балону. Існує спосіб виробництва пустотілих виробів (балонів), які мають форму, близьку до геометрії деталей, гарячим ротаційним обтисканням [1]. Обмеженням методу є складність виготовлення труб з високою чистотою поверхні, що пояснюється зсувом оправки при деформуванні відносно осі заготовки. У результаті утворюється різнотовщинність виробів і збільшуються відходи, які пов'язані з механічним обробленням.

Також має місце при виробництві балонів технологія виготовлення складнопрофільованих пустотілих виробів, при якій частину заготовки нагрівають і деформують у штампі [2]. Поєднання торцевого та радіального деформування забезпечує плин металу в центральних частинах заготовки. Після висаджування ступінчастого профілю вісь виробу формується з використанням оправки [3].

На основі методу скінченних елементів (MCE) О. М. Пасько зі співавторами провів моделювання процесу ротаційного деформування пустотілої циліндричної заготовки. Результати дослідження дозволили встановити, що покрокове деформування призводить до значної неоднорідності параметрів НДС по довжині виробу. Також проводилися дослідження процесу багатоперехідного ротаційного деформування [4]. Ротаційне деформування пустотілих заготовок призводить до збільшення товщини стінки заготовки. Встановлено, що основний вплив на потовщення стінки чинить ступінь обтискання.

У роботі Qi Zhang [5] встановлено, що деформування труби сприяє інтенсивному закриттю отвору й мінімальному подовженню пустотілої заготовки. Однак у досліджені не встановлено форму деформувального інструменту, яка буде сприяти інтенсифікації подовження заготовки.

Z. G. Wang на основі досліджень процесів обтискання труб на радіально-кувальних машинах встановив, що процес сприяє підвищенню механічних властивостей металу [6]. Встановлено вплив ступеня деформування на технологічні параметри обтискання. Відмічено, що подальші дослідження слід спрямувати на встановлення впливу схеми НДС на утворення внутрішньої структури металу, яка впливає на неоднорідність механічних властивостей.

Оцінками критеріїв руйнування при обтисканні труб займався C. Linardon зі співавторами [7]. Вони досліджували процес обтискання різним деформувальним інструментом. У результаті встановлено закономірності зміни тиску деформування в залежності від фактора тертя.

В. В. Сергєєв та співавтори розробили метод виробництва днищ балонів, який полягає в обкочуванні поворотним інструментом нагрітих трубних заготовок. Згідно з цим методом початкова кутова швидкість обертання інструмента становить $(9 \ldots 11) \cdot 10^{-3}$ рад/об., після чого кутова швидкість збільшується до (17...19) $10^{-3}$ рад/об [8]. У роботі не наведено рекомендації щодо вибору ефективної подачі заготовки в інструмент, що є важливим параметром процесу. 
Задача з удосконалення способу виготовлення балонів високого тиску була вирішена Я. І. Літвінським та співавторами шляхом зміни нагрівання кінцевих ділянок заготовок перед обкочуванням [9]. Нагрівання кінцевих ділянок заготовки перед обкочуванням здійснюється так, щоб їх температура послідовно зменшувалася від торця заготовки по іiї довжині. Але розробниками способу не наведено результати досліджень впливу температурного градієнта на заварювання отвору труби.

У дрібносерійному виробництві порожнисті деталі виготовляють ротаційним давильним обробленням, отримуючи вироби з листової заготовки. Ротаційним витягуванням отримують порожнисті вироби з заданим розподілом товщини стінки. При масовому виробництві балонів використовують обкочування: роликами в обоймі, профільними роликами 3 поворотом, валками, що рухаються одночасно в радіальному і осьовому напрямах; роликами, які переміщаються за певною програмою, двома роликами тощо. Виробники устаткування для обкочування випускають універсальні машини обкочування вертикального, горизонтального типів, а також спеціального виконання з різними робочими інструментами. Проте при обкочуванні валками й роликами існують і певні технологічні обмеження. До них відноситься неможливість отримання плоских днищ. Крім того, з'являється істотна різниця окружних швидкостей ролика і заготовки в різних точках контактної поверхні. Останній чинник призводить до прискореного зношення робочої поверхні ролика. В описаному процесі необхідно враховувати, що при переході на інші типорозміри виготовлюваних балонів $є$ істотна складність переналаштування машин обкочування.

Кожен з розглянутих способів виготовлення має як свої переваги, так і недоліки. Одним із перспективних методів виготовлення балонів підвищеної міцності та герметичності $\epsilon$ спосіб використання операції обкочування заготовки з стальної труби інструментом тертя (IT), до того ж це можуть бути і шовні труби. Особливості переваг цього способу, з точки зору зниження собівартості, досягається при виготовлені однотипних балонів партіями від 3-х тисяч, це пояснюється необхідністю виготовлення IT [10]. Ця технологія проста в реалізації та добре піддається автоматизації. Варто також зазначити, що процес виготовлення балонів на основі ротаційного обкочування IT не потребує значних капіталовкладень для створення серійного виробництва в порівнянні з іншими способами. В сучасних економічних умовах важливим $\epsilon$ економія енергоресурсів за рахунок нагрівання заготовки в результаті тертя між заготовкою та IT.

Даний спосіб виготовлення балонів має цілу низку переваг перед іншими в серійному виробництві, але при цьому при порушенні певних технологічних схем [10] виникає серйозний дефект, в частині виробів відсутнє повне заварювання стінки днища внаслідок недостатньої температури та низьким рівнем стискаючих напружень у осьовій зоні днища. Окрім того для тонкостінних заготовок існує ризик перепалення заготовки за рахунок підвищення температури внаслідок тертя заготовки та IT. Тому такі способи виготовлення вимагають удосконалення процесу обкочування IT на основі дослідження факторі,в що впливають на якість продукції.

На сьогодення теоретичні й практичні розробки та дослідження в цьому способі виготовлення відображують регулювання процесу обкочування за окремими напрямками впливу: сил тертя, попереднього нагрівання заготовки, обертів заготовки, подачі заготовки, формоутворення і виготовлення IT та інші [11-15]. Частина розробок отримана теоретичним шляхом, але більшість експериментально.

Мета роботи - встановити вплив температурного режиму обкочування на процес для підвищення якості днищ балонів та ємностей з трубчастих та різнотовщинних трубчатих заготовок.

Об'єкт досліджень: процес виготовлення днищ балонів підвищеної міцності та герметичності ротаційним обкочуванням інструментом тертя. 
Процес обкочування IT проводиться наступним чином: трубчата заготовка закріплюється в патроні токарного верстату, та проводиться локальний нагрів кінця заготовки до температури деформації (рис. 1). На наступному етапі заготовці надають обертання довкола своєї осі, одночасно з цим на заготовку створюється локальний тиск за рахунок руху IT перпендикулярно до осі заготовки. Деформація відбувається в результаті сил тертя та ковзання між трубчатою заготовкою та IT. При цьому відділяється теплова енергія, що приводить підвищення температури заготовки до ковальської.

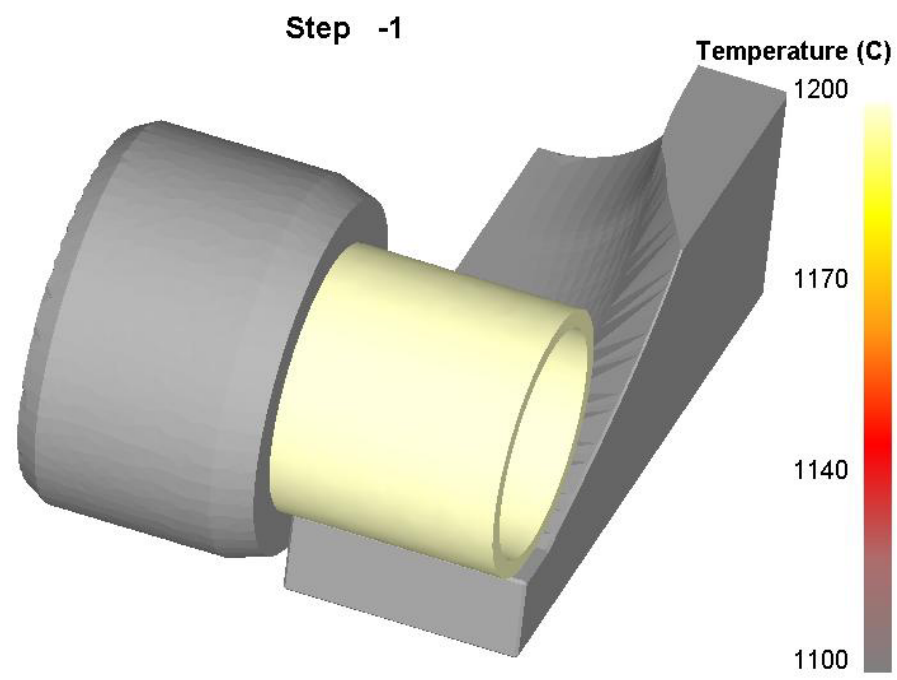

Рис. 1. Скінченно-елементна модель процесу тангенціального обкочування IT трубних заготовок на початковому етапі

Тиск, що створює IT на завершальному етапі, призводить до заварювання отвору в осьовій зоні днища балону ковальським способом зварювання (рис. 2). Остаточної форми днище набуває саме на кінці процесу обкочування IT.

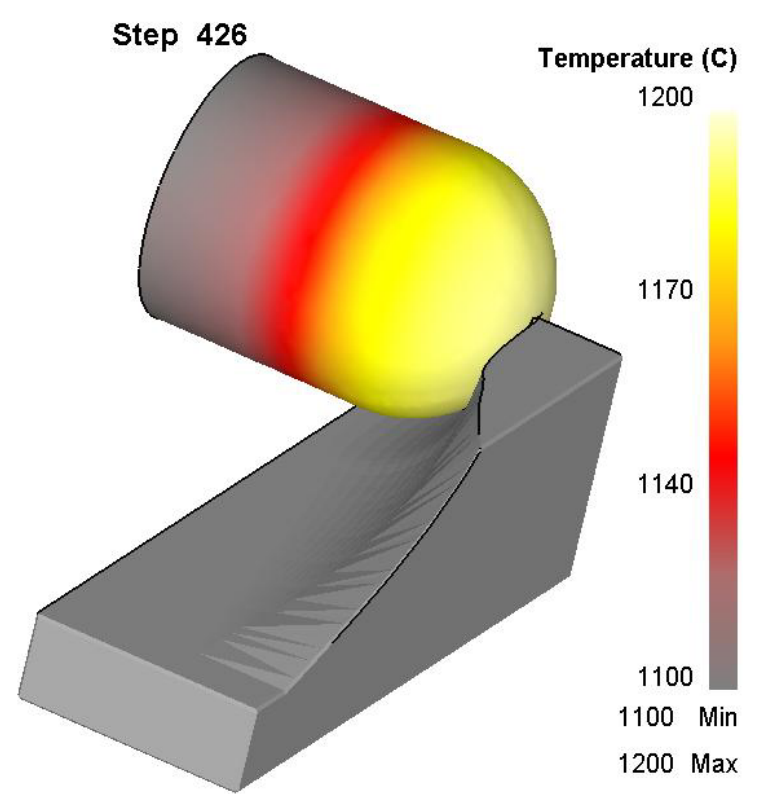

Рис. 2. Скінченно-елементна модель процесу тангенціального обкочування IT на завершальному етапі

Встановлення оптимальних умов температурного режиму згідно з схемою, представленою на рис. 3, проводилось на основі рівняння теплопровідності та методів розв'язку рівнянь математичної фізики [9]. В результаті були отримані залежності для визначення оптимальних вхідних параметрів процесу. 
Так, наприклад , залежність $t=\frac{\mu p \omega b}{3 \alpha}-\left(\frac{\mu p \omega b}{3 \alpha}-t_{i}\right) \exp \left(-\frac{\alpha \tau}{c \rho h_{0}}\right)$ [9] дає змогу визначити температуру заготовки за рахунок тертя між заготовкою та IT. Основними параметрами впливу на цей час будуть: початкова температура заготовки $t_{n}$, кутова швидкість $\omega$ обертання заготовки, час $\tau$ обкочування. В результаті можна отримати граничну температуру процесу деформації в вигляді $t_{2 p}=\frac{\mu p \omega b}{3 \alpha}$. Розрахунок за цією формулою дає для вуглецевих сталей граничну температуру близьку $1200^{\circ} \mathrm{C}$, що підтверджується іншими джерелами. Надалі всі розрахунки та аналіз проводяться в безрозмірному вигляді. Таким чином рекомендація стосовно температури деформації в чисельних методах буде розглядатися в межах від $0,6 T_{\text {гом }}$ до $0,8 T_{\text {гом }}$, гомологічна температура $T_{\text {гом }}$, в нашому випадку, - це відношення поточної температури заготовки до температури плавлення матеріалу заготовки.

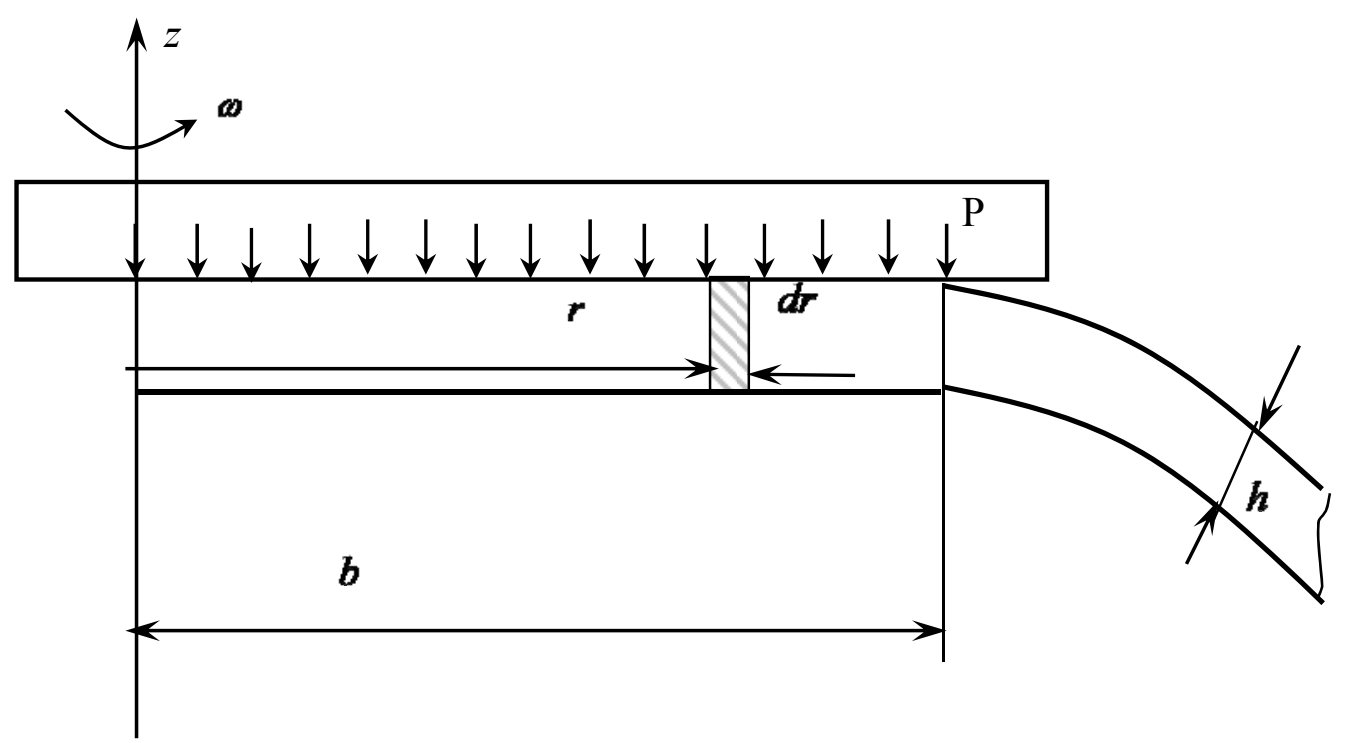

Рис. 3. Схема до розрахунку теплового режиму зони пластичного формозмінення днища

Теоретичні дослідження напружено-деформованого стану (НДС) обкочування IT заготовки проводились на основі теорії оболонок та методу верхньої оцінки [1]. Аналіз НДС заготовки дозволив розбити дослідження за трьома типами заготовок відносної товщини стінок: менше ніж $D / h=10$ - товстостінна, близько $D / h=15$ середньостінна, більше ніж $D / h=20$ - тонкостінна. Тут $D$ - діаметр трубчатої заготовки, $s$ - товщина заготовки. Також були отримані рекомендації відносно подачі заготовки до IT, котра становить $l / D=0,8 \ldots 1,0$ це відношення довжини (вильоту) заготовки відносно IT до діаметру заготовки [9].

Тепловий стан трубчатих заготовок в процесі обкочування IT було встановлено за допомогою МСЕ. За результатами цього дослідження було встановлено температуру днища на час закінчення процесу обкочування. Ця температура буде відповідати температурі, при котрій відбувається зварювання стінок заготовки в осьовій зоні (рис. 4). Дослідження процесу проводилося при різних початкових гомологічних температурах $\left(T_{\text {гом }}\right)$, діапазон температур складав $0,6 \ldots 0,8$. Різнотовщинність стінок заготовки $(D / s)$ варіювалася у діапазоні $10 \ldots 20$. Відносна подача заготовки в IT розглядалася сталою $(l / D=0,9)$.

Аналіз результатів розподілу температур за поздовжнім перерізом дозволив встановити, що температура розподіляється нерівномірно за перерізом заготовки (див. рис. 4). Максимальна температура заготовки досягається та локалізується в осьовій зоні днища, це пояснюється тривалістю контакту заготовки з IT. Мінімальну температуру має заготовка у місці iii фіксації патроном верстата. Відповідний розподіл температур пояснюється максимальним 
розігріванням днища труби та інтенсивним охолодженням заготовки з боку захоплювача верстата. За перерізом пустотілої заготовки при тангенціальному обкочуванні IT градієнт температур не виходить за межі температурного інтервалу гарячого оброблення тиском для співвідношень розмірів модельованої заготовки, але разом з тим існують певні відмінності розподілу температур для заготовок з різною товщиною стінки. Було встановлено, що в процесі обкочування, з початковим нагріванням заготовок з різною товщиною стінки до температур від $900{ }^{\circ} \mathrm{C}$ до $1200{ }^{\circ} \mathrm{C}$, не відбувається охолодження заготовки, тобто розподіл температур дозволяє стверджувати, що підігрівати трубну заготовку не потрібно в процесі обкочування IT. Окрім того, це дозволило встановити початкову температуру заготовки для процесу ротаційного обкочування IT, а саме ця температура повинна бути в межах $1150 \ldots 1200{ }^{\circ} \mathrm{C}$ $\left(T_{\text {гом }}=0,8\right)$. Величина цієї температури достатня для необхідної пластичності металу, мінімізації сили обкочування, досягнення ефекту заварювання стінок в осьовій зоні.

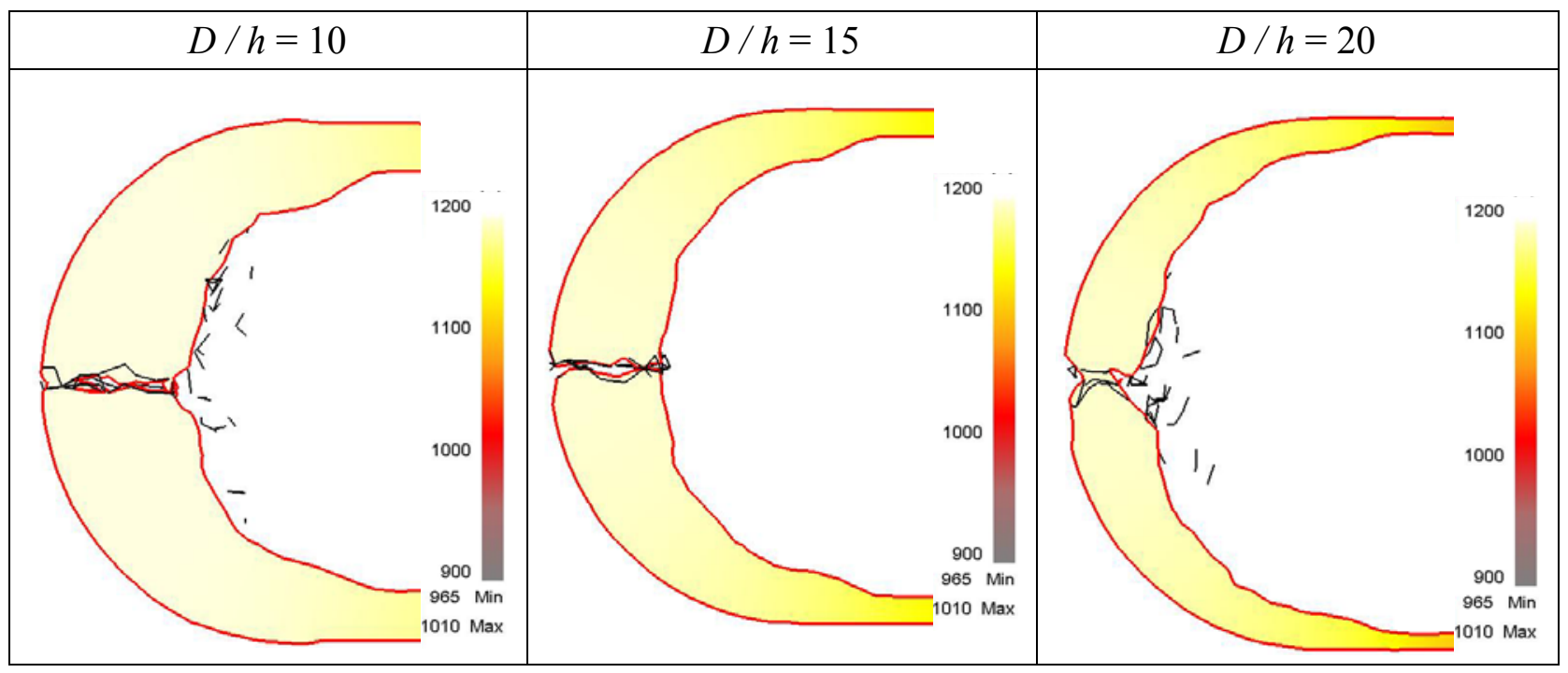

Рис. 4. Розподіл температур у заготовках 3 початковою температурою $T_{\text {гом }}=0,8$ та різною відносною товщиною стінки

При дослідженні МСЕ температурного режиму обкатки заготовки було досліджено 9 різних схем обкочування, котрі розрізняються за варіацією двох параметрів процесу: початкова температура та відносна товщина стінки заготовки.

За результати температурних досліджень МСЕ в залежності від відносної товщини стінок можна зробити певні висновки. Картина розподілу температур в заготовках з відносною товщиною стінки $D / h=10$ має наступну особливість: на внутрішній поверхні днища температура нижча, ніж на зовнішній, цей перепад температур збільшується при зниженні початкової температури нагрівання заготовки. Для тонкостінних заготовок $(D / h=20)$ існує небезпека утворення перегрівання та перепалення металу. Для варіації температури в схемах досліджень характерним $є$ наступне: температура заготовки стрімко під час обкочування зростає за досить короткий час від $T_{\text {гом }}=0,6$ до $T_{\text {гом }}=0,75$. В подальшому швидкість зростання температури зменшується та поступово стабілізується до встановленої. Що ще раз підтверджує експонентний закон зростання температури заготовки.

Окрім цього для забезпечення якості виробу, виникає питання про дослідження процесу за іншими параметрами: виліт заготовки, подача інструменту, швидкість обертання заготовки, оскільки досягнення ковальської температури не гарантує закриття та заварювання отвору в осьовій зоні днища, в особливості для тонкостінних заготовок. Таким чином дослідження МСК температурного режиму процесу обкочування в подальшому повинно окремо поводитись в залежності від відносної заготовки стінок заготовки. 


\section{ВИСНОВКИ}

Проведені дослідження дозволяють встановити, що до початку процесу обкочування оптимальною температурою нагрівання заготовки $є$ температура приблизно рівна $T_{\text {гом }}=0,8$. Підігрівання в процесі обкочування заготовки не потребують. На кінець процесу обкочування заготовки інструментом тертя температура є достатньою для зварювання стінок заготовки в осьовій зоні, але досягнення необхідної температури не гарантує герметичності днища. Для тонкостінних заготовок для запобігання ефектів переплавлення та перегрівання можливе підстужування заготовки або водою, або проведення процесу обкочування в декілька етапів, що потребує додаткових досліджень. Для товстостінних заготовок рекомендується нагрівання проводити максимально близьким до температури $T_{\text {гом }}=0,8$. Слід також зазначити про доцільність проведення досліджень впливу інших факторів процесу обкочування на якість виготовлення днища. Можна припустити, що ці чинники повинні створити додаткове напруження в осьовій зоні.

\section{СПИСОК ВИКОРИСТАНОЇ ЛІТЕРАТУРИ}

1. Ростовщиков В. А. Технология и оборудование для формообразования польх длинномерных поковок горячим радиальным обжатием / В. А. Ростовщиков // Кузнечно-итамповочное производство. - 1987. - № 6. C. $10-13$.

2. Sizek H. W. Radial Forging / H. W. Sizek// Metalworking : Bulk Forming. - 2005. - C. 172-178.

3. Марков О. Е. Разработкка нового способа клвки днищ / О. Е. Марков, В. Ю.Станков, А. О. Шарун, С. В. Ковалевский, М. С. Косилов // Обработка материалов давлением : сб. науч. трудов. - Краматорск, 2017. № 2 (45). - C. 63-66.

4. Пасько А.Н. Моделирование многопереходного процесса ротационной ковки / А. Н. Пасько, О. А. Ткач // Известия ТулГУ. Технические науки. Технологии и оборудование для обработки металлов давлениeм. - 2010. - № 3. - C. 69-73.

5. Rotary swaging forming process of tube workpieces / Qi Zhang, Kaiqiang Jin, Dong mu, Pengju Ma, Jie Tian // 11th International Conference on Technology of Plasticity, ICTP 2014, 19-24 October 2014. - Nagoya Congress Center, Nagoya, Japan. - Procedia Engineering. - 2014. - 81. - P. 2336-2341.

6. Wang Z. G. The theory analysis and numerical simulation for the radial forging process of gun barrel / Wang Z. G. // Nanjing University of Science and Technology. - 2011. - P. 28-30.

7. A conical mandrel tube drawing test designed to assess failure criteria / C. Linardon, D. Favier, G. Chagnon, B. Gruez // Journal of Materials Processing Technology. - 2014. - 214. - P. 347-357.

8. Пат. 39240 Україна, МПК В21D22/16, В21D22/22, В21D51/24. Спосіб виготовлення газових балонів високого тиску / Сергєєв В. В., Іванов А. І., Літвінський Я. І., Янковський В. М., Юр'єв М. П., Мельник В. Г., Карп I. М., П'ятничко О. I. ; власники Державний науково-дослідний та конструкторсько-технологічний інститут трубної промисловості «ДТІ», Відкрите акиіонерне товариство «Бердичівський машинобудівний завод "Прогрес"». - № 2000063308 ; заявл. 06.06.2000 ; опубл. 15.06.2001, Бюл. № 5. - 4 с.

9. Пат. 8581 Украӥна, МПК В21D51/16. Спосіб виготовлення корпусів балонів високого тиску / Сергєєв В. В., Мельник В. Г., Жарко В. П., Літвінський Я. І., Юр'єв М. П., Іванов А. І., Соломадіна С. А., Янковський В. М. ; опубл. 15.08.2005. - 2 c.

10. Шевцуов С. О. Удосконалення технології виробництва днищз балонів на основі обкочування інструментом тертя з підсадкою: монографія / С. О. Шевиов, О. С. Марков, О. М. Кулік. - Краматорськ : ДДМА, 2018. - 128 c. - ISBN 978-966-379-836-3.

11. Пьи Я. Е. Влияние сил трения и смазки на крутящий момент и температуру трубчатых заготовок при ротационной обкатке / Я. Е. Пыц, Е Я. Пыи // Вісник Донбаської державної машинобудівної академії : зб. наук. прайь. - Краматорск : ДДМА, 2018. - № 2 (44). - С. 135-140.

12. Капорович В. Г. Производство деталей из труб обкаткой / В. Г. Капорович. - М. : Машиностроение, 1978. - 136 c.

13. Паламарчук В. А. Квыббору рациональных по энергии режимов тангенциильной обкатки инструментом трения / В. А. Паламарчук // Высокоэффективные локальные методы обработки металлов давлением : Тез. докл. респ. научн.-техн. конф. 29.03.84, Краматорск, 1984. - С. 70-71.

14. Паламарчук В. О. Аналіз роботи деформування заготівок при ротаційній обкатці труб інструментом тертя / В. О. Паламарчук, С. О. Шевцов // Совершенствование прочессов и оборудования обработки давлением в металлургии и машиностроении : Межвуз.сб. научн. трудов. - Краматорськ : ДГМА, 1999. - С. $310-312$.

15. Середа В. Г. Исследование форм днищ для автоматизаџии проектирования инструмента трения / В. Г Середа, В. А. Паламарчук, Е. В. Горбач // Вісник національного технічного університету ХПI «Нові рішення в сучасних технологіях». - Х. : НТУ ХПІ, 2012. - № 47(953). - С. 177-180. 


\section{REFERENCES}

1. Rostovshhikov V. A. Tehnologija i oborudovanie dlja formoobrazovanija polyh dlinnomernyh pokovok gorjachim radial'nym obzhatiem / V. A. Rostovshhikov // Kuznechno-shtampovochnoe proizvodstvo. - 1987. - № 6. - S. 10-13.

2. Sizek H. W. Radial Forging / H. W. Sizek// Metalworking : Bulk Forming. - 2005. - C. 172-178.

3. Markov O. E. Razrabotkka novogo sposoba klvki dnishh / O. E. Markov, V. Ju.Stankov, A. O. Sharun, S. V. Kovalevskij, M. S. Kosilov // Obrabotka materialov davleniem : sb. nauch. trudov. - Kramatorsk, 2017. - № 2 (45). S. 63-66.

4. Pas'ko A. N. Modelirovanie mnogoperehodnogo processa rotacionnoj kovki / A. N. Pas'ko, O. A. Tkach // Izvestija TulGU. Tehnicheskie nauki. Tehnologii i oborudovanie dlja obrabotki metallov davleniem. - 2010. - № 3. S. 69-73.

5. Rotary swaging forming process of tube workpieces / Qi Zhang, Kaiqiang Jin, Dong mu, Pengju Ma, Jie Tian // 11th International Conference on Technology of Plasticity, ICTP 2014, 19-24 October 2014. - Nagoya Congress Center, Nagoya, Japan. - Procedia Engineering. - 2014. - 81. - P. 2336-2341.

6. Wang Z. G. The theory analysis and numerical simulation for the radial forging process of gun barrel / Wang Z. G. // Nanjing University of Science and Technology. - 2011. - P. 28-30.

7. A conical mandrel tube drawing test designed to assess failure criteria / C. Linardon, D. Favier, G. Chagnon, B. Gruez // Journal of Materials Processing Technology. - 2014. - 214. - P. 347-357.

8. Pat. 39240 Ukraïna, MPK B21D22/16, B21D22/22, B21D51/24. Sposib vigotovlennja gazovih baloniv vi-

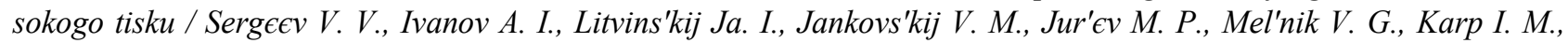
P'jatnichko O. I. ; vlasniki Derzhavnij naukovo-doslidnij ta konstruktors'ko-tehnologichnij institut trubnoï promislovosti «DTI», Vidkrite akcionerne tovaristvo «Berdichivs'kij mashinobudivnij zavod "Progres"». - № 2000063308 ; zajavl. 06.06.2000; opubl. 15.06.2001, Bjul. № 5. - 4 s.

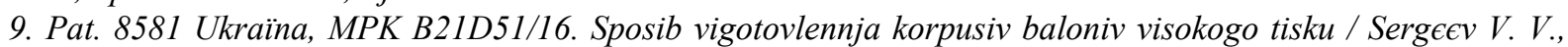
Mel'nik V. G., Zharko V. P., Litvins'kij Ja. I., Jur'єv M. P., Ivanov A. I., Solomadina C. A., Jankovs'kij V. M. ; opubl. 15.08.2005. $-2 s$.

10. Shevcov S. O. Udoskonalennja tehnologï virobnictva dnishh baloniv na osnovi obkochuvannja instrumentom tertja z pidsadkoju: monografija / S. O. Shevcov, O. C. Markov, O. M. Kulik. - Kramators'k : DDMA, 2018. - 128 s. ISBN 978-966-379-836-3.

11. Pyc Ja. E. Vlijanie sil trenija i smazki na krutjashhij moment i temperaturu trubchatyh zagotovok pri rotacionnoj obkatke / Ja. E. Pyc, E Ja. Pyc // Visnik Donbas'koï derzhavnoï mashinobudivnoï akademï : zb. nauk. prac'. Kramatorsk, : DDMA, 2018. - № 2 (44). - S. 135-140.

12. Kaporovich V. G. Proizvodstvo detalej iz trub obkatkoj / V. G. Kaporovich. - M. : Mashinostroenie, 1978. - $136 \mathrm{~s}$

13. Palamarchuk V.A. Kvyboru racional'nyh po jenergii rezhimov tangencial'noj obkatki instrumentom trenija / V. A. Palamarchuk // Vysokojeffektivnye lokal'nye metody obrabotki metallov davleniem : Tez. dokl. resp. nauchn.-tehn. konf. 29.03.84, Kramatorsk, 1984. - S. 70-71.

14. Palamarchuk V. O. Analiz roboti deformuvannja zagotivok pri rotacijnij obkatci trub instrumentom tertja / V. O. Palamarchuk, S. O. Shevcov // Sovershenstvovanie processov i oborudovanija obrabotki davleniem v metallurgii $i$ mashinostroenii : Mezhvuz. sb. nauchn. trudov. - Kramators'k: DGMA, 1999. - S. 310-- 312.

15. Sereda V. G. Issledovanie form dnishh dlja avtomatizacii proektirovanija instrumenta trenija / V. G. Sereda, V. A. Palamarchuk, E. V. Gorbach // Visnik nacional'nogo tehnichnogo universitetu HPI «Novi rishennja v suchasnih tehnologijah». - H. : NTU HPI, 2012. - № 47(953). - S. 177-180.

Шевцов С. О. - канд. техн. наук, ст. викл. каф. ВМ ДДМА.

ДДМА - Донбаська державна машинобудівна академія, м. Краматорськ.

E-mail: sheser.ssa1@gmail.com 